\title{
Article \\ Soil Efflux of Carbon Dioxide in Brazilian Cerrado Wheat (Triticum aestivum L.) under Variable Soil Preparation and Irrigation
}

\author{
Wininton M. da Silva 1,*, Aloísio Bianchini ${ }^{2}$, Ricardo S. S. Amorim ${ }^{3} \mathbb{D}$, Eduardo G. Couto ${ }^{2} \mathbb{D}$, \\ Oscarlina L. dos S. Weber ${ }^{2}$, Aaron Kinyu Hoshide ${ }^{4}\left(\mathbb{D}\right.$, Pedro S. X. Pereira ${ }^{2}$, Cassiano Cremon ${ }^{5}$ (D) \\ and Daniel C. de Abreu 6,7 (iD
}

Citation: Silva, W.M.d.; Bianchini, A.; Amorim, R.S.S.; Couto, E.G.; Weber,

O.L.d.S.; Hoshide, A.K.; Pereira,

P.S.X.; Cremon, C.; Abreu, D.C.d. Soil Efflux of Carbon Dioxide in Brazilian Cerrado Wheat (Triticum aestivum L.) under Variable Soil Preparation and Irrigation. Agriculture 2022, 12, 163. https://doi.org/10.3390/

agriculture12020163

Academic Editors: Chang Oh Hong and Sang Yoon Kim

Received: 22 December 2021

Accepted: 20 January 2022

Published: 24 January 2022

Publisher's Note: MDPI stays neutral with regard to jurisdictional claims in published maps and institutional affiliations.

Copyright: () 2022 by the authors. Licensee MDPI, Basel, Switzerland. This article is an open access article distributed under the terms and conditions of the Creative Commons Attribution (CC BY) license (https:// creativecommons.org/licenses/by/ $4.0 /)$.
1 Empresa Mato-Grossense de Pesquisa, Assistência e Extensão Rural (EMPAER-MT), Centro Político Administrativo, Cuiabá 78049-903, MT, Brazil

2 Programa de Pós-Graduação em Agricultura Tropical, Universidade Federal de Mato Grosso, Cuiabá 78060-900, MT, Brazil; bianchi@cpd.ufmt.br (A.B.); couto@ufmt.br (E.G.C.); oscarlina.weber@ufmt.br (O.L.d.S.W.); pedro.sxp@hotmail.com (P.S.X.P.)

3 Departamento de Engenharia Agrícola, Universidade Federal de Viçosa, Viçosa 36570-900, MG, Brazil; rsamorim@ufv.br

4 College of Natural Sciences, Forestry and Agriculture, The University of Maine, Orono, ME 04469, USA; aaron.hoshide@maine.edu

5 Department of Agronomy, Universidade do Estado de Mato Grosso, Rua São João, s/n., Caceres 78216-596, MT, Brazil; cassiano.cremon@unemat.br

6 AgriSciences, Universidade Federal de Mato Grosso, Caixa Postal 729, Sinop 78550-970, MT, Brazil; abreu@ufmt.br

7 Instituto de Ciências Agrárias e Ambientais, Campus Universitário de Sinop, Universidade Federal de Mato Grosso, Avenida Alexandre Ferronato, 1200, Sinop 78555-267, MT, Brazil

* Correspondence: winintonsilva@empaer.mt.gov.br; Tel.: +55-(65)-999241470

\begin{abstract}
Soil turning during pre-seeding preparation is meant to loosen and promote physical characteristics responsible for the development of crop roots in soil. In this study, we demonstrate effects of three methods of pre-seeding preparation at two depths of irrigation on carbon dioxide $\left(\mathrm{CO}_{2}\right)$ efflux as well as the temporal variability in the distribution of soil carbon. This experiment was conducted at the rural cooperative extension research station in Tangará da Serra, Mato Grosso, Brazil, for two wheat production years in 2011 and 2012. The experimental design was randomized in strips, with four repetitions. Wheat was irrigated during the June to early October dry season. The treatments include two methods of soil preparation: traditional preparation with one plowing and two disc harrowings and minimal preparation with one seed bed conditioner pass. A third treatment of direct seeding was also evaluated. Soil $\mathrm{CO}_{2}$ efflux, soil temperature, air-filled soil porosity, and labile carbon were measured. We found soil preparation affects $\mathrm{CO}_{2}$ efflux in irrigated cultivation systems within Brazil's Cerrado savannah, with conventional tillage having greater $\mathrm{CO}_{2}$ emissions than either reduced tillage or direct seeding. Soil $\mathrm{CO}_{2}$ emissions were lower at $508 \mathrm{~mm}$ versus $698 \mathrm{~mm}$ irrigation depth, but wheat yields were significantly lower.
\end{abstract}

Keywords: cultivation; carbon emissions; dry season; labile carbon; savannah; South America; watering; yield

\section{Introduction}

Long-term sequestration of carbon dioxide $\left(\mathrm{CO}_{2}\right)$ within agricultural systems has focused on soil organic matter [1] where cereals such as wheat (Triticum aestivum L.) can transfer 20-30\% of assimilated carbon into soils [2]. Short-term emphasis has been focused on quantifying greenhouse gas (GHG) emissions from agriculture and developing recommendations to reduce such emissions such as $\mathrm{CO}_{2}$, methane, and nitrous oxide. The $\mathrm{CO}_{2}$ emissions from soils can be 11 times those from combustion of fossil fuels [3]. Soil turning 
during pre-seeding preparation (e.g., plowing, tillage) is meant to loosen and promote physical attributes responsible for aeration, water filtration, and development of roots in soil $[4,5]$. However, such soil preparation for crops such as wheat combined with adequate soil temperature and/or moisture can increase GHG emissions from soil [6-9], though see Eshel et al. [10].

In addition to damaging soil structure, soil preparation prior to planting crops can increase the efflux (i.e., emission) of soil carbon dioxide $\left(\mathrm{CO}_{2}\right)$ from agriculture. By breaking soil aggregates some of the labile organic carbon that was protected within the interior of the aggregate is exposed to micro-biotic degradation, and stocks are reduced over time [11,12]. The efflux of $\mathrm{CO}_{2}$ caused by soil turning may reach metric tons over the span of weeks $[13,14]$. Prior research also showed that the husks of sugar cane incorporated into soil, together with the breakage of soil aggregates with a rotary hoe, may lead to an increase in the efflux of $\mathrm{CO}_{2}$ equivalent to 3\% of the total carbon of the residue incorporated [15].

Alterations in other soil variables such as soil temperature [16,17], soil moisture [18,19], soil aeration porosity [20], or labile carbon [21], may determine the quantity of carbon emitted by agriculture. In tropical soils, soil temperature is not always the controlling factor for carbon efflux. This is due to the effect of soil moisture on $\mathrm{CO}_{2}$ efflux, as soil moisture and soil temperature are interdependent variables that simultaneously vary [22]. Moreover, in tropical regions, soil temperature is near ideal for micro-biotic activity [23]. This may explain why various research papers on agricultural systems have reported soil moisture as the principal factor in soil $\mathrm{CO}_{2}$ emissions $[13,24,25]$.

In irrigated systems, soil water can be controlled through irrigation frequency, which is dependent on the physiological characteristics of the irrigated culture (related to water consumption), the preparation of soil, climate, and soil type [26]. Soil moisture as a controlling factor important to the loss of soil $\mathrm{C}$ is a given based on the knowledge that varying methods of pre-seeding soil preparation promote varying impacts on the amount of carbon emitted from soil, through both efflux and leaching. Corroborating this point, Moitinho et al. [27] describe how increasing the soil water content through irrigation, leads to the significant removal of $\mathrm{CO}_{2}$ when the water enters into the soil pore space. Regarding the leaching of soil dissolved organic carbon (DOC) in agriculture, Beesley [28] shows high mobility of DOC until $0.3 \mathrm{~m}$, and many peaks of DOC production throughout the year that may contribute to leaching. Leaching of DOC accounts for approximately $25 \%$ of the net loss of carbon in agriculture and pasture ecosystems, when losses from harvesting and fire are excluded amongst others [29].

Understanding the effects caused by different soil preparation techniques on irrigated agricultural systems is important for understanding their impacts on agro-ecosystems. These impacts include GHG emissions such as $\mathrm{CO}_{2}$ efflux from soil, which can be evaluated to help select cropping systems that balance crop production with environmental sustainability for a given area. As such, the impact of three methods of pre-seeding preparation and two irrigation depths on the efflux of $\mathrm{CO}_{2}$ and the temporal variation of labile soil carbon stocks were investigated for wheat grown during a third potential cropping window within a given calendar year in Brazil's Cerrado biome.

\section{Materials and Methods}

This experiment was conducted during the 2011 and 2012 dry seasons at the Empresa Mato-Grossense de Pesquisa, Assistência e Extensão Rural (EMPAER) research station in Tangará da Serra, Mato Grosso (MT) $\left(14^{\circ} 40^{\prime} \mathrm{S}\right.$ and $\left.57^{\circ} 25^{\prime} \mathrm{W}\right)$, Brazil. The climate of the region has a Köppen classification of 'tropical-Am', with two distinct periods, a rainy period between November and March and a dry period between April and October. The pluviometer-measured mean annual precipitation is $1830.8 \mathrm{~mm}$, and the mean annual temperature is $25.2{ }^{\circ} \mathrm{C}$ [30].

The soil was classified as typical Dystrophic Red Latosols, following the Brazilian Soil Classification System [31] with clayey texture, which along with physical and chemical attributes during the two years of cultivation are presented in Tables 1 and 2. Analysis of 
soil samples was conducted in three separate laboratories. Soil chemical attributes were analyzed in Agroanalysis, a commercial laboratory in the city of Cuiabá in the state of Mato Grosso (MT), Brazil. Soil physical characteristics were measured in the soil physics laboratory at the Universidade Federal do Mato Grosso (UFMT) campus in Cuiabá, MT, Brazil. Soil labile carbon content was analyzed in the soil chemistry laboratory also located at the UFMT campus in Cuiabá.

Table 1. Chemical attributes ${ }^{a}$ of soils with different preparations under the cultivation of irrigated wheat in 2011 and 2012 in Tangará da Serra, Mato Grosso state, Brazil.

\begin{tabular}{|c|c|c|c|c|c|c|c|c|c|}
\hline Preparation & Depth (m) & $\mathrm{pH} \mathrm{H}_{2} \mathrm{O}$ & $\mathbf{P}$ & $\mathrm{K}$ & $\mathrm{Ca}+\mathrm{Mg}$ & SB & CEC7 & BS & SOM \\
\hline & & & \multicolumn{2}{|c|}{$\mathrm{mg} \mathrm{dm}^{-3}$} & & \multicolumn{2}{|l|}{$\mathrm{cmol}_{\mathrm{c}} \mathrm{dm}^{-3}$} & $\%$ & $\mathrm{~g} \mathrm{dm}^{-3}$ \\
\hline & \multicolumn{9}{|c|}{2011} \\
\hline \multirow{3}{*}{ Implementation } & $0.0-0.1$ & 6.2 & 3.8 & 2.5 & 7.5 & 8.2 & 14.3 & 57.5 & 51.2 \\
\hline & $0.1-0.2$ & 6.1 & 1.7 & 2.2 & 6.8 & 7.4 & 13.3 & 55.4 & 48.0 \\
\hline & \multicolumn{9}{|c|}{2012} \\
\hline \multicolumn{10}{|l|}{ Soil Preparation } \\
\hline \multirow{2}{*}{ Conventional } & $0.0-0.1$ & 5.9 & 7.8 & 2.4 & 7.5 & 8.2 & 17.3 & 47.7 & 55.8 \\
\hline & $0.1-0.2$ & 6.1 & 1.5 & 2.5 & 7.1 & 7.8 & 14.4 & 53.9 & 52.7 \\
\hline \multirow{2}{*}{ Minimal } & $0.0-0.1$ & 5.7 & 5.2 & 2.4 & 6.3 & 7.0 & 16.0 & 43.9 & 54.2 \\
\hline & $0.1-0.2$ & 5.8 & 3.2 & 2.6 & 6.0 & 6.6 & 14.3 & 46.0 & 51.2 \\
\hline \multirow{2}{*}{ Direct Seeding } & $0.0-0.1$ & 5.9 & 2.2 & 2.2 & 7.4 & 8.1 & 17.0 & 47.6 & 57.4 \\
\hline & $0.1-0.2$ & 6.2 & 2.2 & 2.8 & 7.2 & 7.7 & 14.0 & 55.3 & 52.7 \\
\hline \multirow{2}{*}{ Woods } & $0.0-0.1$ & 6.3 & 2.8 & 2.3 & 10.8 & 11.6 & 19.5 & 59.3 & 59.2 \\
\hline & $0.1-0.2$ & 6.2 & 1.2 & 2.5 & 10.3 & 10.9 & 18.3 & 59.5 & 55.8 \\
\hline
\end{tabular}

${ }^{a}$ Soils from experimental treatments tested for $\mathrm{pH}$, phosphorus $(\mathrm{P})$, potassium $(\mathrm{K})$, calcium $(\mathrm{Ca}+)$, magnesium $(\mathrm{Mg})$, sum of exchangeable bases (SB), cation exchange capacity at pH 7.0 (CEC7), base saturation (BS), and soil organic matter (SOM).

Table 2. Physical attributes ${ }^{a}$ of soils with different preparations under the cultivation of irrigated wheat in 2011 and 2012 in Tangará da Serra, Mato Grosso state, Brazil.

\begin{tabular}{|c|c|c|c|c|c|c|c|c|c|}
\hline \multirow{2}{*}{ Preparation } & Layer & Sand & Silt & Clay & BD & MaP & MiP & TP & SRPfc \\
\hline & $\mathrm{cm}$ & & $\mathrm{g} \mathrm{kg}^{-1}$ & & $\mathrm{Mg} \mathrm{m}^{-3}$ & $\mathrm{~m}^{3} \mathrm{~m}^{-3}$ & $\mathrm{~m}^{3} \mathrm{~m}^{-3}$ & $\mathrm{~m}^{3} \mathrm{~m}^{-3}$ & Mpa \\
\hline & \multicolumn{9}{|c|}{2011} \\
\hline \multirow{3}{*}{ Implementation } & $0.0-0.1$ & 84 & 218 & 698 & 1.09 & 0.14 & 0.43 & 0.57 & 0.94 \\
\hline & $0.1-0.2$ & 66 & 199 & 699 & 1.12 & 0.11 & 0.45 & 0.56 & 0.97 \\
\hline & \multicolumn{9}{|c|}{2012} \\
\hline \multicolumn{10}{|l|}{ Soil Preparation } \\
\hline \multirow{2}{*}{ Conventional } & $0.0-0.1$ & 123 & 195 & 682 & 1.07 & 0.16 & 0.42 & 0.58 & 0.92 \\
\hline & $0.1-0.2$ & 107 & 202 & 691 & 1.12 & 0.11 & 0.45 & 0.56 & 0.86 \\
\hline \multirow{2}{*}{ Minimal } & $0.0-0.1$ & 156 & 179 & 665 & 1.06 & 0.17 & 0.42 & 0.59 & 1.34 \\
\hline & $0.1-0.2$ & 156 & 182 & 662 & 1.12 & 0.11 & 0.45 & 0.56 & 0.75 \\
\hline \multirow{2}{*}{ Direct Seeding } & $0.0-0.1$ & 123 & 195 & 682 & 1.13 & 0.11 & 0.44 & 0.56 & 1.47 \\
\hline & $0.1-0.2$ & 90 & 222 & 688 & 1.11 & 0.12 & 0.44 & 0.57 & 1.00 \\
\hline \multirow{2}{*}{ Woods } & $0.0-0.1$ & 223 & 184 & 593 & 0.85 & 0.22 & 0.46 & 0.68 & 1.05 \\
\hline & $0.1-0.2$ & 190 & 178 & 632 & 0.87 & 0.21 & 0.44 & 0.65 & 1.13 \\
\hline
\end{tabular}

${ }^{\text {a }}$ Soils from experimental treatments were measured for soil particle content and for soil Bulk Density (BD), soil Macroporosity (MaP), soil Microporosity (MiP), soil Total Porosity (TP), and Soil Resistance to Penetration at field capacity (SRPfc). 
Wheat was planted using a grain drill in the June to early October dry season which represents the third possible cropping window in Brazil following soybeans-corn (Figure 1). Before planting in both years, $350 \mathrm{~kg}$ of the 22-04-12 nitrogen-phosphorus-potassium (NPK) formulation was applied in the sowing row for fertilization. Wheat was planted on 4 June 2011 and on 25 June 2012. Planting was delayed in 2012 due to initial poor establishment necessitating re-planting. Topdressing fertilization was applied 18 days after planting using the same amount as pre-plant fertilization. According to the recommendations made for the crop, in the vegetative stages V1 and V2, the commercial products RoundUp ${ }^{\circledR}$ WG (2.0 $\left.\mathrm{kg} \mathrm{ha}^{-1}\right)$, Sovereign (0.2 L ha $\left.{ }^{-1}\right)$, Hero $\left(0.2 \mathrm{~L} \mathrm{ha}^{-1}\right)$, and Primóleo (5.0 L ha-1) were applied as agricultural pesticides. In stage V4, commercial products Hero $\left(0.2 \mathrm{~L} \mathrm{ha}^{-1}\right)$ and Exalt $\left(0.1 \mathrm{~L} \mathrm{ha}^{-1}\right)$ were applied. All crop protection materials were purchased at Agrounidos, located at Av. Miguel Sutil, 14372 Coopamil, Cuiabá, MT, Brazil 78025-700.

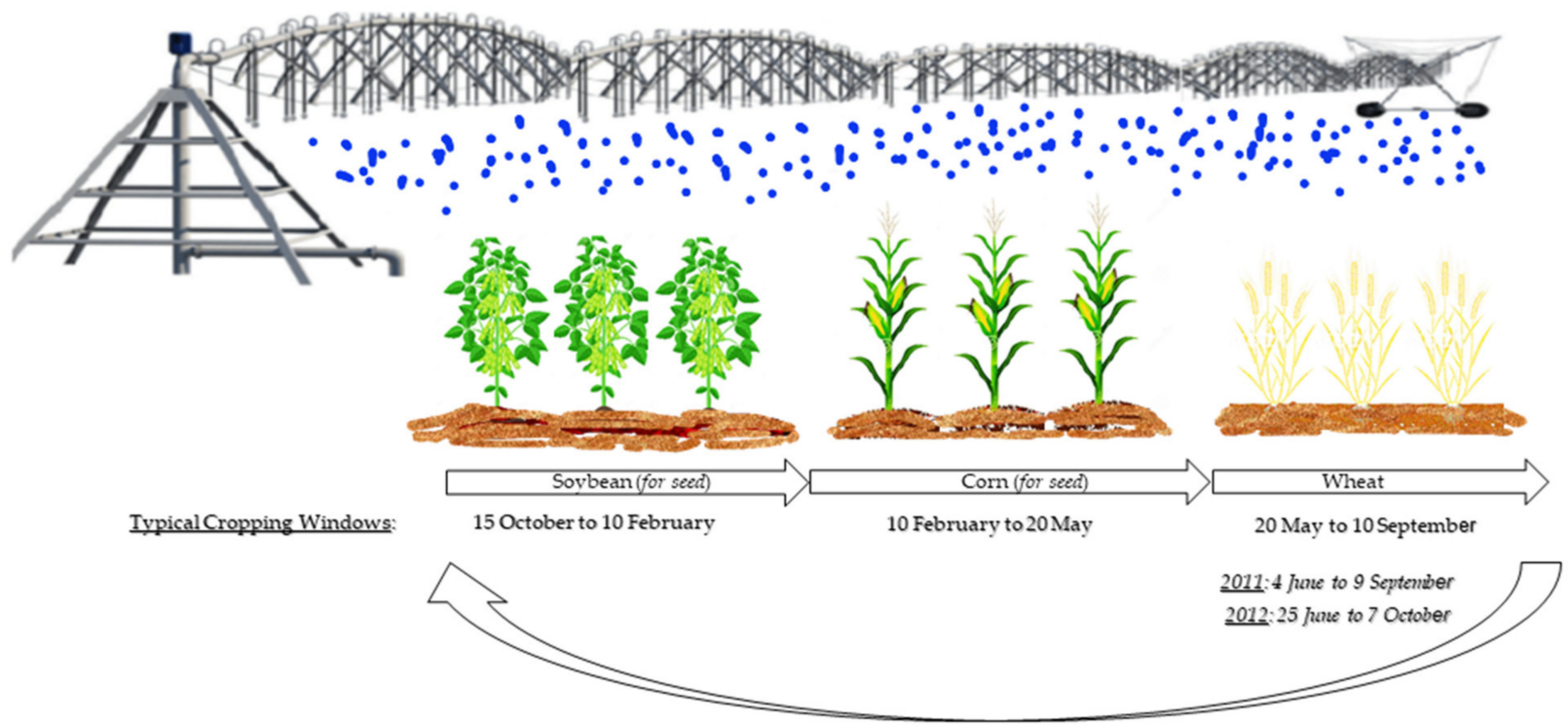

Figure 1. Typical annual triple-crop rotation for irrigated crops in Cerrado, Brazil.

The experimental design was of randomized strips, with four repetitions (Figure 2). Our treatments consisted of three soil preparation methods: conventional with one plowing followed by two passes with a disc harrow with soil turning to $\pm 0.2 \mathrm{~m}(\mathrm{CP})$; minimal preparation with one pass using a seed bed conditioner turning approximately the top $0.1 \mathrm{~m}$ of soil (MP); and direct seeding (DS). DS was completed with a seeder equipped for 15 lines spaced $0.17 \mathrm{~m}$ apart and a seeding density of 350 seeds $\mathrm{m}^{-2}$, and the BRS-264 cultivar (non-transgenic). Fertilization at seeding consisted of $500 \mathrm{~kg} \mathrm{ha}^{-1}$ of NPK 04-30-16 plus application of $10 \mathrm{~kg} \mathrm{ha}^{-1}$ of FTE Borogran 10 ( $8 \%$ boron) to control the sterility of male grains. For fertilization after germination, $60 \mathrm{~kg} \mathrm{ha}^{-1}$ of nitrogen $(\mathrm{N})$ from urea (45-0-0) was applied using a tractor pulled spin spreader.

Two watering depths were applied, 508 and $698 \mathrm{~mm}$, for experiments on cultivated wheat in 2011 and 2012. The sprinkler irrigation (Figure 2) frequency was controlled using two tensiometers installed at 0.2 and $0.4 \mathrm{~m}$, distributed throughout the experimental plots, aiming to always keep the pore water potential at the optimal value for wheat production, $-40 \mathrm{Kpa}$ within the top $0.2 \mathrm{~m}$ of the soil column [32]. Rainfall was limited since wheat was grown during the dry season. During the 2011 crop season, there was only $0.03 \mathrm{~mm}$ measured at the WatchDog 2000 series meteorological station installed in the experimental area during the entire study period. Since the 2012 crop was re-planted, there was more recorded precipitation from 7 June to 8 September $2012(8 \mathrm{~mm})$ and 9 September to 7 October $2012(80 \mathrm{~mm})$ as grain ripening was pushed closer to the start of the wet season. 


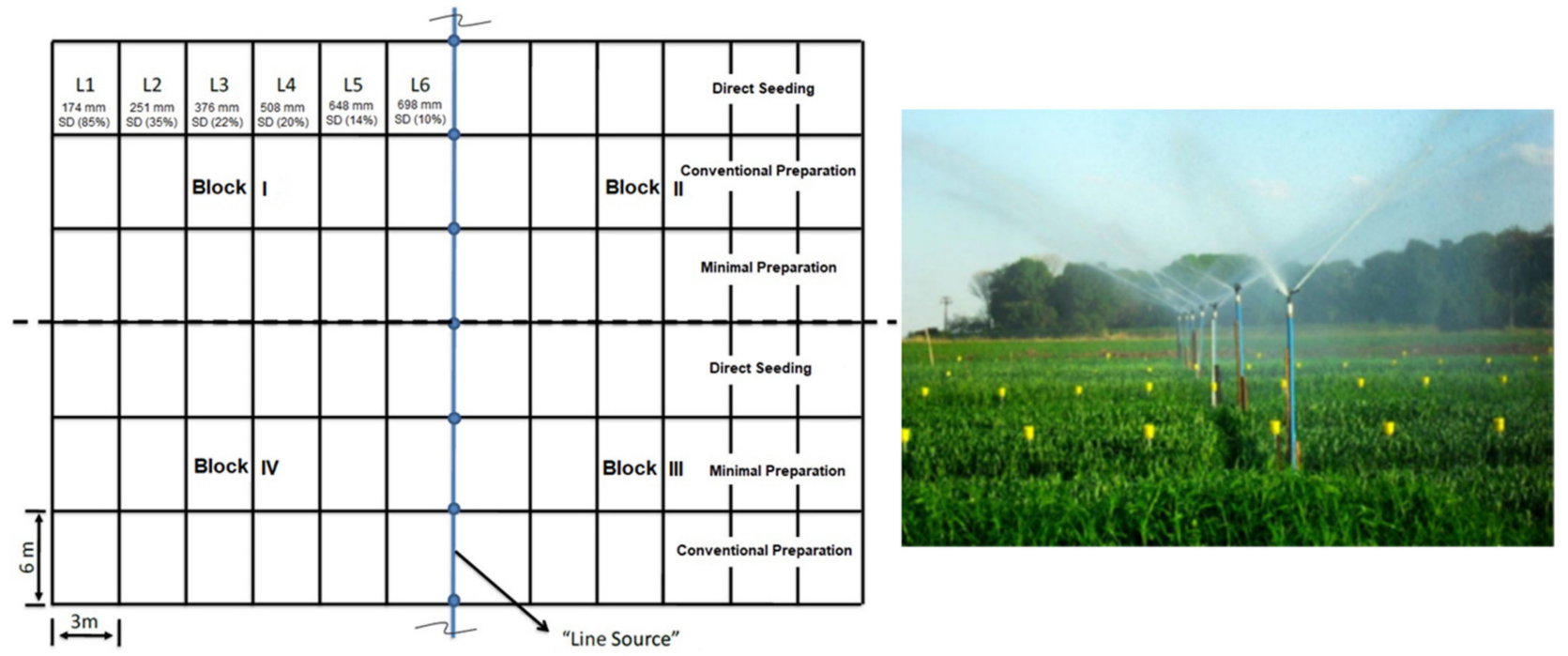

Figure 2. Experimental design field map and irrigation for cultivation of wheat in 2011 and 2012 in Tangará da Serra, Mato Grosso state, Brazil. Photo: Thales A.D. Daniel, 2011.

Variables evaluated were $\mathrm{CO}_{2}$ efflux, soil temperature, soil moisture, and labile carbon content during six phases of the development of the wheat culture. Soil efflux was measured using an EGM-4 gas analyzer (PP Systems International, Inc., Amesbury, MA, USA) that includes an internal humidity sensor fixed to a closed chamber (PPS-SRC-1 Soil Respiration Chamber) and a soil temperature sensor (STP-1 Soil Temperature Probe). Three soil respiration chambers were installed to measure $\mathrm{CO}_{2}$ efflux per parcel with $0.5 \mathrm{~m}$ between chambers. Measurements were taken between 10:00 am and 12:00 pm in six periods over the course of the experiment in two growing years (2011 and 2012).

Soil samples $(n=24)$ were collected for the two soil preparation treatments and the direct seeding treatment for two irrigation depths. The net $\mathrm{CO}_{2}$ efflux from soil during the study period was calculated integrating the area under the efflux curve as measured over time (during six phases of wheat development), as shown in Equation (1):

$$
E f a c=\sum_{k=1}^{n} \frac{E f_{k}+E f_{k-1}}{2} \times I j
$$

where $E f a c$ is the net efflux of $\mathrm{CO}_{2}\left(\mathrm{Mg} \mathrm{ha}^{-1}\right) ; \mathrm{Ef}$ is the efflux of $\mathrm{CO}_{2}\left(\mathrm{Mg} \mathrm{ha}^{-1}\right) ; k$ is the moment of measurement of efflux; $n$ is the number of the measurement; $j$ is the time interval (in days) between the measurements.

Concurrently with measurements of soil $\mathrm{CO}_{2}$ efflux were measurements of soil temperature, made with the sensor attached to the EGM-4, and soil water volume, measured through undisturbed samples [31] collected at the $0-0.1 \mathrm{~m}$ layer. The air-filled soil porosity (AFSP in $\mathrm{m}^{3} \mathrm{~m}^{-3}$ ) was calculated as the difference between the soil porosity (TP in $\mathrm{m}^{3} \mathrm{~m}^{-3}$ ) and the soil water volume [33]. Labile soil carbon was determined in the $0-0.2 \mathrm{~m}$ layer and quantified by oxidation with $\mathrm{KMnO}_{4}\left(33 \mathrm{mmol} \mathrm{L}^{-1}\right)$, as proposed by Blair et al. [34] and modified by Shang and Tiessen [35]. As data collection were collected in similar periods between the two years of experimental evaluation, samples were tested to see if data from the two years could be combined. Data were combined when the quotient between the highest and lowest mean residual of the individual analysis of variance for each experiment was less than seven [36].

After this analysis, a second analysis of variance of the sub-divided plots was completed to determine the treatment effect. Treatment means were separated by bootstrapping 1000 random samples with replacement, following the methodology of [37]. From the 1000 values, upper and lower limits of the $95 \%$ confidence interval around the mean were calculated, and used to compare means [38]. In this manner, means with common values 
within the confidence intervals do not show a difference, and means without common values within the confidence intervals show significant differences (using Tukey's test with 95\% probability).

Wheat was damaged by capybara (Hydrochoerus hydrochaeris) nocturnal grazing in both years impacting $60 \%$ of plantings in 2011 despite use of a perimeter fence. In 2012 even after upgrading to an electric fence, capybara damage was still $40 \%$. While not a preferred food source [39], our planting of irrigated wheat was attractive to these herbivores during the dry season. Wheat yield was sampled on 9 September 2011 and 7 October 2012. Sampling was focused as much as possible in the center of plots and involved three transects per plot with each transect measuring $3 \mathrm{~m} \times 6 \mathrm{~m}=18$ square meters. Plots for each soil preparation system were averaged and then converted to yield per hectare ( 1 ha $=10,000$ square meters). The average moisture content of harvested wheat grain was $13 \%$. Random transects of whole wheat plants were sampled for counting (plants $\mathrm{m}^{-2}$ ) and grain yield measurement in areas within plots that were not damaged from capybara grazing in order to estimate crop yields per ha for experimental treatments.

\section{Results and Discussion}

\subsection{Soil Carbon Dioxide Emissions}

The emission of $\mathrm{CO}_{2}$ varied across all soil preparation methods between 0.74 and $3.22 \mathrm{~g} \mathrm{~m}^{-2} \mathrm{~h}^{-1}$ with a mean of $1.52 \pm 0.48$ for the irrigation depth of $508 \mathrm{~mm}$ (L508) and between 0.78 and $2.95 \mathrm{~g} \mathrm{~m}^{-2} \mathrm{~h}^{-1}$ with a mean of $1.77 \pm 0.47$ for the $698 \mathrm{~mm}$ irrigation depth (L698). As shown in Table 3, deeper irrigation was associated with significantly more $\mathrm{CO}_{2}$ efflux even for direct seeding. Soil $\mathrm{CO}_{2}$ emissions for both years for all three soil preparation method are shown in Table 3, where soil $\mathrm{CO}_{2}$ efflux was significantly greater for conventional tillage (1.81 to $2.01 \mathrm{~g} \mathrm{~m}^{-2} \mathrm{~h}^{-1}$ ) compared to minimal tillage (1.51 to $\left.1.66 \mathrm{~g} \mathrm{~m}^{-2} \mathrm{~h}^{-1}\right)$ or direct seeding (1.24 to $\left.1.64 \mathrm{~g} \mathrm{~m}^{-2} \mathrm{~h}^{-1}\right)$. There were no statistically significant differences in soil temperature nor labile carbon content across treatments. Airfilled soil pore space was significantly greater for plots with soil preparation compared to those that were direct seeded (Table 3).

The analysis of variance showed significant interaction between the soil preparations and irrigations depths, with the highest $\mathrm{CO}_{2}$ emissions for the conventional preparation (CP) for both irrigation depths analyzed. This result is consistent with assertions made in other studies that postulate that greater soil mobilization leads to greater impacts on $\mathrm{CO}_{2}$ emissions $[13,14,40]$. The absence of soil turning led to a reduction in the emission of $\mathrm{CO}_{2}$ and demonstrated a significant effect of irrigation depth on efflux to the atmosphere. Soil moisture is considered the most important controlling factor in tropical soil $\mathrm{CO}_{2}$ emissions $[24,41,42]$. This is corroborated by past research $[27,43]$ which suggests that irrigation can cause significant $\mathrm{CO}_{2}$ emissions when water enters into soil pore space, stimulating microbial activity, increasing microbial productivity and resulting atmospheric emissions [13,41]. Moreover, the presence of wheat further increases the $\mathrm{CO}_{2}$ emission upon irrigation through the liberation of root exudates that also stimulate soil microbial activity $[44,45]$.

Mean values of $\mathrm{CO}_{2}$ emission for conventional preparation are higher than those reported by [46] in an irrigated eutrophic Red Latossol in Jaboticabal, São Paulo with clayey texture. That study showed that for an area cleared of vegetation, disc plowed and harrowlevelled (conventional preparation) the mean emission is $1.88 \mu$ mols $\mathrm{m}^{-2} \mathrm{~s}^{-1}$. Similar emission rates as found in the current study were reported by Silva-Olaya et al. [24], who relate mean emission of $1.89 \mathrm{~g} \mathrm{~m}^{-2} \mathrm{~h}^{-1}$ for conventional soil preparation (one plow and two harrows) 13 days after first tillage operation and after a rainfall event of $25 \mathrm{~mm}$. The same authors report a $93 \%$ increase from the day prior to the rainfall event $\left(0.98 \mathrm{~g} \mathrm{~m}^{-2} \mathrm{~h}^{-1}\right)$ in the treatment with conventional preparation and 50\% increase in the no-till treatment. This reinforces the importance of soil moisture in increasing $\mathrm{CO}_{2}$ emissions from soil and the reduction of soil disturbance during preparation as a strategy to mitigate such emissions under irrigated conditions. 
Table 3. Descriptive statistics ${ }^{\mathrm{a}}$ of $\mathrm{CO}_{2}$ efflux, soil temperature, air-filled soil porosity and labile carbon in the $0-0.20 \mathrm{~m}$ soil layer for irrigation depths of 508 and $698 \mathrm{~mm}$ and differing soil preparation methods averaged over 2011 and 2012 wheat crop dry seasons.

\begin{tabular}{|c|c|c|c|c|c|c|c|c|c|c|c|c|}
\hline \multirow[b]{2}{*}{ Preparation ${ }^{b}$} & \multicolumn{6}{|c|}{$508 \mathrm{~mm}$ Irrigation Depth } & \multicolumn{6}{|c|}{$698 \mathrm{~mm}$ Irrigation Depth } \\
\hline & Mean $^{c}$ & SD & Min & $\operatorname{Max}$ & UL & LL & Mean $^{c}$ & SD & Min & Max & UL & LL \\
\hline Soil Prep. & \multicolumn{12}{|c|}{$\mathrm{CO}_{2}$ emission $\left(\mathrm{g} \mathrm{m}^{-2} \mathrm{~h}^{-1}\right)$} \\
\hline Conv. & $1.81 \mathrm{aA}$ & 0.54 & 0.79 & 3.10 & 0.22 & 0.20 & $2.01 \mathrm{aA}$ & 0.47 & 1.04 & 2.70 & 0.18 & 0.21 \\
\hline Minimal & $1.51 \mathrm{abA}$ & 0.56 & 0.84 & 3.22 & 0.25 & 0.20 & $1.66 \mathrm{bA}$ & 0.44 & 0.83 & 2.41 & 0.17 & 0.18 \\
\hline Direct Sd. & $1.24 \mathrm{bB}$ & 0.33 & 0.74 & 1.97 & 0.13 & 0.12 & $1.64 \mathrm{bA}$ & 0.56 & 0.78 & 2.95 & 0.21 & 0.22 \\
\hline Soil Prep. & \multicolumn{12}{|c|}{ Soil Temperature $\left({ }^{\circ} \mathrm{C}\right)$} \\
\hline Conv. & 21.33 n.s. & 1.46 & 21.33 & 26.67 & 0.54 & 0.57 & 24.50 n.s. & 2.77 & 21.00 & 31.00 & 1.17 & 1.04 \\
\hline Minimal & 21.33 n.s. & 1.31 & 21.33 & 26.33 & 0.54 & 0.51 & 24.25 n.s. & 1.89 & 22.00 & 28.00 & 0.88 & 0.67 \\
\hline Direct Sd. & 21.00 n.s. & 1.10 & 21.00 & 25.00 & 0.39 & 0.44 & 24.13 n.s. & 2.03 & 22.00 & 29.00 & 0.79 & 0.71 \\
\hline Soil Prep. & \multicolumn{12}{|c|}{ Labile Carbon (mg g ${ }^{-1}$ soil) } \\
\hline Conv. & 2.04 n.s. & 0.30 & 1.75 & 2.34 & 0.12 & 0.13 & 1.97 n.s. & 0.31 & 1.62 & 2.36 & 0.18 & 0.16 \\
\hline Minimal & 2.04 n.s. & 0.35 & 1.50 & 2.42 & 0.12 & 0.13 & 2.03 n.s. & 0.25 & 1.75 & 2.41 & 0.21 & 0.18 \\
\hline Direct Sd. & 2.02 n.s. & 0.28 & 1.70 & 2.30 & 0.11 & 0.12 & 1.98 n.s. & 0.36 & 1.64 & 2.55 & 0.09 & 0.10 \\
\hline Soil Prep. & \multicolumn{12}{|c|}{ Air-filled Soil Pore Space $\left(\mathrm{m}^{3} \mathrm{~m}^{-3}\right)$} \\
\hline Conv. & $0.21 \mathrm{aA}$ & 0.07 & 0.05 & 0.34 & 0.02 & 0.03 & $0.19 \mathrm{aA}$ & 0.05 & 0.11 & 0.31 & 0.02 & 0.02 \\
\hline Minimal & $0.20 \mathrm{aA}$ & 0.07 & 0.04 & 0.32 & 0.03 & 0.03 & $0.18 \mathrm{abA}$ & 0.05 & 0.11 & 0.29 & 0.02 & 0.02 \\
\hline Direct Sd. & $0.18 \mathrm{bA}$ & 0.09 & 0.06 & 0.39 & 0.03 & 0.04 & $0.14 \mathrm{bA}$ & 0.05 & 0.07 & 0.22 & 0.02 & 0.02 \\
\hline & & $\begin{array}{l}\text { a S } \\
\text { UL } \\
\text { Cor } \\
\text { cas } \\
\text { pre } \\
\text { are }\end{array}$ & $\begin{array}{l}\text { ary st } \\
\text { wer L } \\
\text { Conv } \\
\text { rs in } \\
\text { ions a } \\
\text { ndica }\end{array}$ & $\begin{array}{l}\text { s inc } \\
\text { and } \mathrm{u} \\
\text { nal p } \\
\text { ins ar } \\
\text { igati }\end{array}$ & $\begin{array}{l}\mathrm{SD}= \\
\text { Lim } \\
\text { ation } \\
\text { per c } \\
\text { pths }\end{array}$ & $\begin{array}{l}\text { dard } \\
\text { the co } \\
\text { imal } \\
\text { etters } \\
\text { ding }\end{array}$ & $\begin{array}{l}\text { viation, Mi } \\
\text { dence inte } \\
\text { Minimal pr } \\
\text { ows indica } \\
\text { ukey tests }\end{array}$ & $\begin{array}{l}\text { Minin } \\
\text { resp } \\
\text { ation } \\
\text { gnific }\end{array}$ & $\begin{array}{l}\text { valu } \\
\text { vely. } \\
\text { ile Di } \\
\text { differ }\end{array}$ & $\begin{array}{l}\mathrm{ax}=\mathrm{N} \\
\text { prepa } \\
\text { Sd. = I } \\
\text { betw } \\
\text { as that }\end{array}$ & $\begin{array}{l}\text { num } \\
\text { on (Pr } \\
\text { ct See } \\
\text { mean }\end{array}$ & $\begin{array}{l}\text {, LL } \\
\text { inclu } \\
\text { c Lo } \\
\text { s for }\end{array}$ \\
\hline
\end{tabular}

\subsection{Contrast with and Context within Prior Research}

This variability of $\mathrm{CO}_{2}$ efflux between production systems with similar soil preparation methods reinforces the complexity of this phenomenon and highlights the importance of region and cultivation conditions. Despite their variability, the controlling variables of the production and emission process are dependent on temporary, local edaphoclimatic conditions [40]. There was no effect of soil preparation or irrigation depth on soil temperature or labile carbon. However, a significant effect was observed on air-filled soil pore space depending on soil preparation method. Specifically, increasing the intensity of soil preparation increased the soil air-filled pore space $(\mathrm{CP}>\mathrm{MP}>\mathrm{DS})$. In this way, the increase in pore space opens pathways for greater gas exchange between the soil-atmosphere system, and leads to greater net losses of carbon from the soil via $\mathrm{CO}_{2}$ efflux. When separated by growth phase, there was no significant effect of soil preparation or irrigation depth on soil air-filled pore space (PPar) from 0 to $0.2 \mathrm{~m}$ (Figure $3 \mathrm{a}, \mathrm{b}$ ).

The results shown in Figure 3 suggest that soil preparation, irrigation, and the growth of wheat significantly affect the dynamics of $\mathrm{CO}_{2}$ efflux and its controlling variables. During the planting stage until elongation (40 days after seeding), which is the daily irrigation period, there was a significant effect of soil preparation (CP and MP) on the increase in $\mathrm{CO}_{2}$ efflux (Figure 3a). Significant increases in $\mathrm{CO}_{2}$ efflux have been shown after soil preparation in both short-term and long-term in experiments [13,47-51]. Past research [40] reports significantly higher $\mathrm{CO}_{2}$ efflux from conventional soil preparation, when compared with conventional subsoiling and localized subsoiling 17 days after soil movement, corroborating the results of the current study. Further corroborating our results are other studies $[13,14]$ that report tons of $\mathrm{CO}_{2}$ emitted over a few weeks in tilled versus untilled soil plots. This occurs due to the loosening of soil that leads to increases in the 
decomposition rate of labile $\mathrm{C}$ (constant-K), in turn due to the increased oxygenation and transport of gasses [52,53].

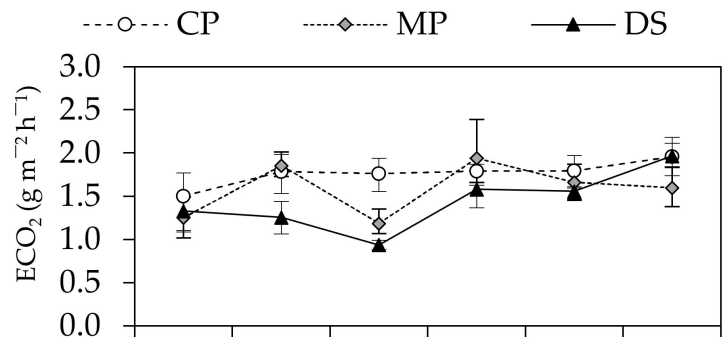

(a)

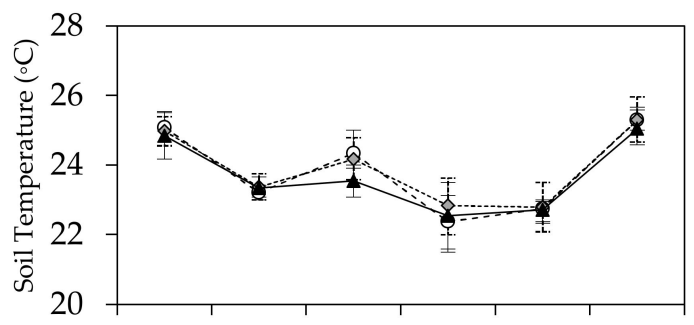

(c)

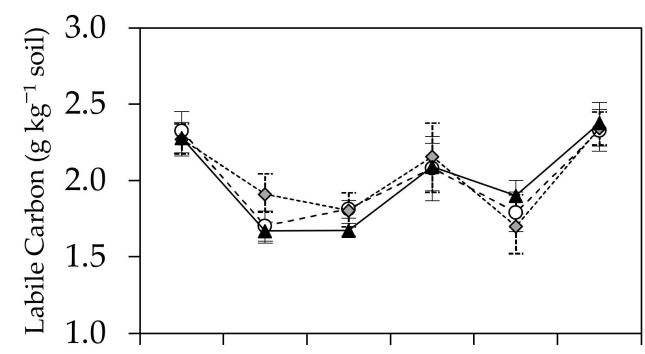

(e)

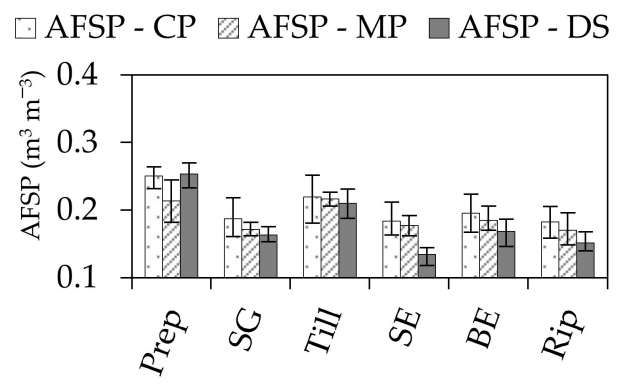

(g)

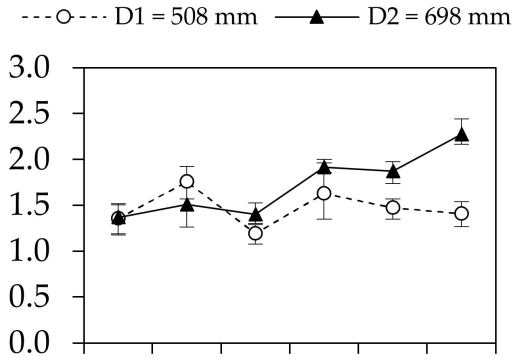

(b)

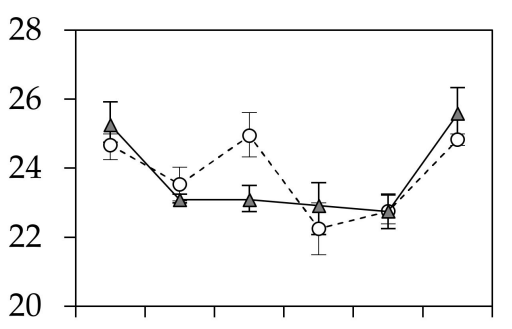

(d)

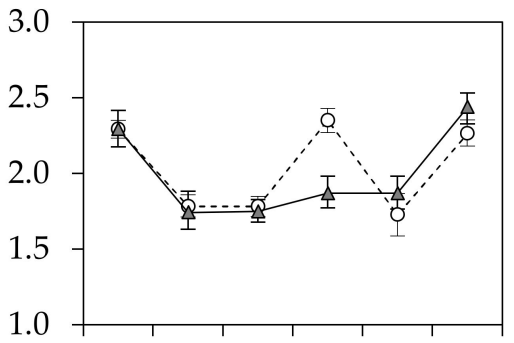

(f)

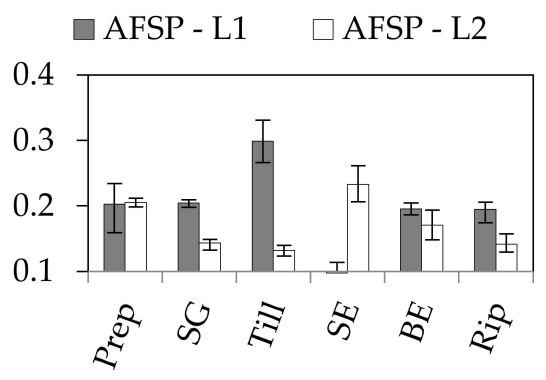

(h)

Figure 3. (a,c,e,g) Effect of Soil Preparation, Growth Stage of Wheat; $(\mathbf{b}, \mathbf{d}, \mathbf{f}, \mathbf{h})$ Effect of Irrigation Depth, Growth Stage of Wheat; $(\mathbf{a}, \mathbf{b}) \mathrm{ECO}_{2}\left(\mathrm{~g} \mathrm{~m}^{-2} \mathrm{~h}^{-1}\right) ;(\mathbf{c}, \mathbf{d})$ Soil Temperature $\left({ }^{\circ} \mathrm{C}\right) ;(\mathbf{e}, \mathbf{f})$ Labile Carbon ( $\mathrm{g} \mathrm{kg}^{-1}$ soil); (g,h) AFSP $\left(\mathrm{m}^{3} \mathrm{~m}^{-3}\right)$; (a-h) Mean $\mathrm{CO}_{2}$ Efflux $\left(\mathrm{ECO}_{2}\right)$, soil temperature, labile carbon, and Air-Filled Soil Pore (AFSP) space in response to variable soil preparation and irrigation depth, throughout six stages of development of wheat collected over 2 years (2011 and 2012) of measurements: Prep = soil Preparation (measurement made $4 \mathrm{~h}$ after soil turning); SG = Seedling Growth; Till = Tillering; $\mathrm{SE}=$ Stem Elongation; $\mathrm{BE}=$ Booting Emergence; Rip = Ripening. 
During the elongation stage of wheat, which coincides with the interruption in daily irrigation and the implementation of tensiometer controlled irrigation frequency, the effect of soil preparation on $\mathrm{CO}_{2}$ efflux is no longer present. This result shows that from this stage onward, wheat begins to control $\mathrm{CO}_{2}$ emission independent from the soil preparation. This is due to factors such as increased soil shading from plant above-ground biomass [54], rapid soil drying through plant water absorption [55], and increasing destruction of soil aggregates from root growth and dry-wet cycling of the soil $[56,57]$.

When there is root growth of plants, there is a resulting breakage of soil aggregates that exposes labile carbon that had been protected by minerals and stimulates microbial activity through the release of root exudates [44]. This process of breakage is also intensified through cycles of wetting and drying of the soil that is related to the irrigation frequency, and the associated contraction and expansion of the soil [58]. This is especially true in clayrich soils [59], such as those studied here, and results in greater carbon losses. The higher irrigation depth caused greater efflux of $\mathrm{CO}_{2}$ in the final growth stages of wheat (booting and flowering), after periodic irrigation is established (Figure 3b). This result collaborates those of many studies in tropical soils that show the greater importance of soil moisture as the key variable influencing $\mathrm{CO}_{2}$ efflux when compared to soil temperature $[25,27,60]$.

Soil temperature did not show any correlation with variations in soil air-filled pore space $(p>0.05)$ during the same period of evaluation (Figure 3c,g). Only during the tillering stage was there a significant effect of soil preparation on the soil temperature $(p<0.05)$, with higher temperatures observed in plowed or harrowed soil as compared to those the direct seeding (Figure 3c). In this case, it is likely that there was an effect of the incorporation of organic residues from the surface during preparation that helps protect the soil from direct sunlight. This result highlights the importance of soil cover with vegetative residues for the maintenance of soil temperature [26], a technique that reduces evapotranspiration in irrigated areas and contributes to the efficient use of water in irrigated production systems.

Temporal variation in soil temperature and labile carbon (Figure $3 c, e$ ) are independent of the preparation method, and show strong correlation $(\mathrm{R}=0.75 ; p<0.05)$. This explains the tendency for increased labile carbon when soil temperatures reach or surpass $25^{\circ} \mathrm{C}$ that coincide with reduced ground cover (soil preparation and ripening). A number of studies show that $25^{\circ} \mathrm{C}$ is considered optimal for microbial activity in soil [61-63]. Within this context, Huang et al. [64] showed that in controlled conditions within incubation chambers labile carbon increased $100 \%$ when soil temperatures were maintained between 15 and $25^{\circ} \mathrm{C}$, and when temperatures were increased to between 25 and $35^{\circ} \mathrm{C}$, the increase was $30 \%$.

Temporal variations in soil air-filled pore space (AFSP) were significantly lower for the greater irrigation depth $(p<0.05)$ in $80 \%$ of measurements during the growth of wheat (Figure $3 g$ ). The lower PPar for the greater irrigation depth is associated with the higher values of $\mathrm{CO}_{2}$ efflux after the establishment of periodic irrigation (elongation stage) can be seen in Figure 3b, and reinforces the assertion that irrigation may cause greater carbon losses through the removal of $\mathrm{CO}_{2}$ from soil pore space [27]. Both soil preparation and irrigation depth showed significant effects on the efflux of $\mathrm{CO}_{2}$ from soil (Figure 4).

The results of this study corroborate previous research concluding that soil preparation as well as irrigation influence soil $\mathrm{CO}_{2}$ emissions [6,41]. Greater soil disturbance during preparation induced higher emissions under conventional preparation, whereas the emissions of the minimal preparation were not different from those of direct seeding. This suggests that minimal preparation may be an alternative preparation method that would reduce compaction in irrigated areas of the Cerrado without resulting in large impacts in the loss of soil carbon. The greater cumulative emission for the $698 \mathrm{~mm}$ irrigation depth indicates that more research is needed to find irrigation depths that are both economically and environmentally sustainable for irrigated crops in the Cerrado, given that the decision to increase the irrigation depth will impact soil carbon losses. Efficient irrigation management based on lower irrigation depths can contribute to reduction in $\mathrm{CO}_{2}$ emissions from agriculture [65]. 


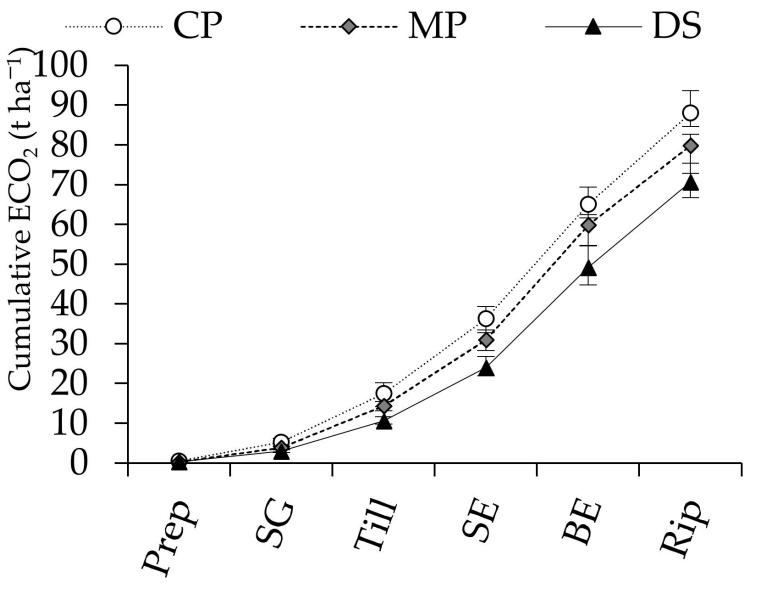

(a)

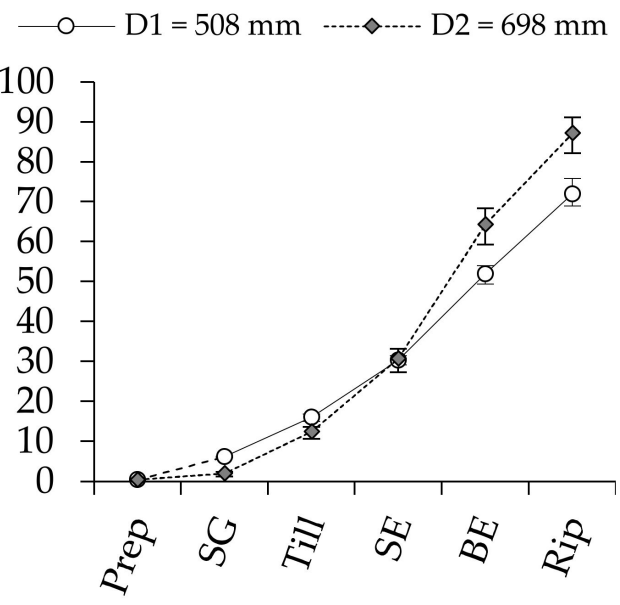

(b)

Figure 4. (a) Effect of Soil Preparation; (b) Effect of Irrigation Depth; $(\mathbf{a}, \mathbf{b})$ Cumulative $\mathrm{CO}_{2}$ efflux (Cumulative $\mathrm{ECO}_{2}\left(\mathrm{t} \mathrm{ha}^{-1}\right)$ ) across the stages of development of irrigated wheat with varying soil preparation methods and irrigation depths, Tangará da Serra, 2012; SG = Seedling Growth; Till = Tillering; $\mathrm{ST}=$ Stem Elongation; $\mathrm{BE}=$ Booting Emergence; Rip = Ripening .

Our study is the first to measure $\mathrm{CO}_{2}$ efflux for wheat grown in tropical climates. Most prior measurements of $\mathrm{CO}_{2}$ efflux in tropical agricultural systems have been for sugar cane $[25,27,33,46,60]$. Research on increased $\mathrm{CO}_{2}$ efflux for wheat from tillage has been predominantly from temperate climates such as China [6-8] and the USA [9]. Future research should verify if $\mathrm{CO}_{2}$ efflux can be reduced with shallower irrigation while not impacting wheat yields. In our study, we did not vary rates of fertilization nor lime and we did not measure greenhouse gases other than $\mathrm{CO}_{2}$ such as methane $\left(\mathrm{CH}_{4}\right)$ and nitrous oxide $\left(\mathrm{N}_{2} \mathrm{O}\right)$. Past research suggests that higher rates of fertilization for winter wheat in northern China can increase $\mathrm{N}_{2} \mathrm{O}$ efflux $[3,66]$ while not impacting $\mathrm{CO}_{2}$ nor $\mathrm{CH}_{4}$ emissions from soil [66]. Furthermore, a lab study suggests that use of lime can increase $\mathrm{CO}_{2}$ efflux [67] so this could be verified in-field.

Plant density and estimated yield are contrasted in Table 4 for soil preparation/planting and irrigation treatments. Wheat plant density was not significantly different between soil preparation and/or seeding treatments for both experimental years. Estimated wheat yield ( $\mathrm{kg} /$ hectare) was significantly greater for more irrigation $(698 \mathrm{~mm})$ compared to less $(508 \mathrm{~mm})$ with the exception of for direct seeding in 2011. Yields were not significantly different between conventional and minimal soil preparation and direct seeding in 2011. However, after a second year, yields for conventional tillage was significantly lower than the treatments with less soil disruption. Thus, there appears to be an interaction effect of irrigation depth and soil tillage on wheat yield, with greater crop yield with more irrigation and direct sowing of the crop.

Our yields with $698 \mathrm{~mm}$ of irrigation were within the range of yields for 76 trials in the Cerrado from 2004 to 2013 [68]. Although >90\% of Brazil's wheat is grown southern Brazil [69] and Mato Grosso was responsible for only 0.7\% from 2000 to 2005 [70], genetic improvement for drought tolerance in the Cerrado is a priority [69]. Irrigated wheat here can be higher yielding [68] with better seed quality [71], especially if evapotranspiration losses from the crop do not exceed 15\% [72]. However, the $6.766 \mathrm{~kg} \mathrm{ha}^{-1}$ higher yield for each additional $\mathrm{mm}$ of irrigation water from $508 \mathrm{~mm}$ to $698 \mathrm{~mm}$ applied (Table 4) comes at the expense of increasing $\mathrm{CO}_{2}$ efflux by $15.2 \mathrm{t} \mathrm{ha}^{-1}$ over the entire cropping season (Figure 4). Brazil's wheat production has shifted from conventional tillage to reduced tillage and no-till in both rainfed and irrigated areas [73]. If this trend of reduced soil disturbance continues, our results show that this is favorable in terms of both productivity (Table 4) and reduction in $\mathrm{CO}_{2}$ emissions from soil (Figure 4). However, the results from our study suggest further reductions in $\mathrm{CO}_{2}$ efflux come at the expense of potentially reducing wheat 
yield in irrigated systems in Brazil's Cerrado. Future research can determine if farm profits from wheat production is consistent with longer term yield differences between systems by including the costs of irrigation and cultivation in enterprise budget calculations.

Table 4. Plant density and estimated irrigated wheat yield with different soil preparations in 2011 and 2012 in Tangará da Serra, Mato Grosso state, Brazil.

\begin{tabular}{|c|c|c|c|c|}
\hline \multirow{2}{*}{$\begin{array}{l}\text { Soil Preparation } \\
\text { and/or Planting }\end{array}$} & \multicolumn{2}{|c|}{$508 \mathrm{~mm}$ Irrigation Depth } & \multicolumn{2}{|c|}{$698 \mathrm{~mm}$ Irrigation Depth } \\
\hline & Plants $\mathrm{m}^{-2}$ a & $\begin{array}{c}\text { Est. Yield } \\
\left(\mathrm{kg} \mathrm{ha}^{-1}\right)^{\mathrm{b}}\end{array}$ & Plants $\mathrm{m}^{-2} \mathrm{a}$ & $\begin{array}{l}\text { Est. Yield } \\
\left(\mathrm{kg} \mathrm{ha}^{-1}\right)^{\mathrm{b}}\end{array}$ \\
\hline & \multicolumn{4}{|c|}{2011} \\
\hline \multicolumn{5}{|l|}{ Soil Preparation } \\
\hline Conventional & 52 n.s. & $3764.24 \mathrm{aB}$ & 57 n.s. & $4243.47 \mathrm{aA}$ \\
\hline Minimal & 48 n.s. & $3401.98 \mathrm{aB}$ & 57 n.s. & $5627.66 \mathrm{aA}$ \\
\hline \multirow[t]{2}{*}{ Direct Seeding } & 64 n.s. & $4604.56 \mathrm{aA}$ & 53 n.s. & $4666.89 \mathrm{aA}$ \\
\hline & \multicolumn{4}{|c|}{2012} \\
\hline \multicolumn{5}{|l|}{ Soil Preparation } \\
\hline Conventional & 58 n.s. & $3055.90 \mathrm{bB}$ & 56 n.s. & $4101.53 \mathrm{bA}$ \\
\hline Minimal & 61 n.s. & $3532.63 \mathrm{abB}$ & 56 n.s. & $4688.31 \mathrm{abA}$ \\
\hline Direct Seeding & 59 n.s. & $4066.52 \mathrm{aB}$ & 59 n.s. & $5352.06 \mathrm{aA}$ \\
\hline
\end{tabular}

a Differences between means for plant density not significant (n.s.). ${ }^{b}$ Lower case letters in columns and upper case letters in rows indicate significant differences between mean values for estimated wheat yield according to Tukey tests at $95 \%$ confidence.

\section{Conclusions}

Soil preparation is directly related to $\mathrm{CO}_{2}$ efflux in irrigated crop systems for wheat in the Cerrado, with greater emissions associated with greater soil disturbance. Increasing the irrigation depth leads to greater cumulative $\mathrm{CO}_{2}$ efflux from the soil. Our data show that the choice of soil preparation technique and irrigation depth, as well as the development of the crop itself, cause variability in the $\mathrm{CO}_{2}$ efflux and related controlling variables, including stocks of labile carbon in the soil. Despite Brazil's shift to no-till annual cropping systems for soybeans, corn, cotton, and other crops (e.g., wheat) which may reduce $\mathrm{CO}_{2}$ efflux, tillage is used for deep phosphorus application and for crops that are not genetically modified for herbicide resistance. Our results demonstrate that reduced tillage and no-till irrigated wheat systems in Brazil's Cerrado can be both higher yielding with lower $\mathrm{CO}_{2}$ emissions than conventional tillage. We also show that irrigation can be managed for more shallow application to reduce $\mathrm{CO}_{2}$ emissions from soil but at the expense of lower wheat yield.

Author Contributions: Conceptualization, D.C.d.A. and W.M.d.S.; methodology, W.M.d.S.; field experiment and data collection, P.S.X.P. and W.M.d.S.; validation, W.M.d.S.; formal analysis, A.B., C.C., E.G.C., O.L.d.S.W., P.S.X.P., R.S.S.A. and W.M.d.S.; investigation, all authors; resources, A.K.H., D.C.d.A. and W.M.d.S.; writing-original draft preparation, A.K.H. and W.M.d.S.; writing-review and editing, all authors; visualization, A.K.H. and W.M.d.S.; supervision, E.G.C.; project administration, D.C.d.A. and W.M.d.S.; funding acquisition, A.B., C.C., E.G.C., O.L.d.S.W. and R.S.S.A. All authors have read and agreed to the published version of the manuscript.

Funding: This research was funded by the Foundation for the Support of Research of the State of Mato Grosso (Fundação de Amparo à Pesquisa do Estado de Mato Grosso-FAPEMAT). CAPES also funded the graduate fellowship of the lead author. This research was also supported by Instituto de Ciências Agrárias e Ambientais (ICAA), Serviço Nacional de Aprendizagem Rural de Mato Grosso (SENAR-MT), Programa Global REDD Early Movers de Mato Grosso (REM-MT), and Projeto Rural Sustentável-Cerrado (PRS-Cerrado). The APC was funded by journal article reviews for MDPI journals conducted by Aaron K. Hoshide from 2020 to 2021 (96.9\%) and by AgriSciences (3.1\%).

Institutional Review Board Statement: Not applicable. 


\section{Informed Consent Statement: Not applicable.}

Data Availability Statement: Experimental data available via request to lead author. Our study did not use outside data sources.

Acknowledgments: The authors would like to thank the Post-Graduate Program in Tropical Agriculture of the Federal University of Mato Grosso (PPGAT-UFMT) for support in addition to their employers and families for supporting this work. Special thanks the ICAA, SENAR-MT, REM-MT, and PRS-Cerrado for the support and incentive for the publication of this study. We also thank two anonymous reviewers for suggested edits and improvements.

Conflicts of Interest: The authors declare no conflict of interest. Supporting entities had no role in the design of the study; in the collection, analyses, or interpretation of data; in the writing of the manuscript, or in the decision to publish the results.

\section{References}

1. Kuzyakov, Y. Sources of $\mathrm{CO}_{2}$ efflux from soil and review of partitioning methods. Soil Biol. Biochem. 2006, 38, 425-448. [CrossRef]

2. Kuzyakov, Y.; Domanski, G. Carbon input by plants into the soil. Review. J. Plant. Nutr. Soil Sci. 2000, 163, 421-431. [CrossRef]

3. Shao, R.; Deng, L.; Yang, Q.; Shangguan, Z. Nitrogen fertilization increase soil carbon dioxide efflux of winter wheat field: A case study in Northwest China. Soil Till. Res. 2014, 143, 164-171. [CrossRef]

4. Schiavo, J.A.; Colordro, G. Agregação e resistência à penetração de um Latossolo Vermelho sob sistema de integração. Bragantia 2012, 71, 406-412. [CrossRef]

5. Guan, D.; Zhang, Y.; Al-Kaisi, M.M.; Wang, Q.; Zhang, M.; Li, Z. Tillage practices effect on root distribution and water use efficiency of winter wheat under rain-fed condition in the North China Plain. Soil Till. Res. 2015, 146 Pt B, 286-295. [CrossRef]

6. Dong, W.; Hu, C.; Chen, S.; Zhang, Y. Tillage and residue management effects on soil carbon and $\mathrm{CO}_{2}$ emission in a wheat-corn double-cropping system. Nutr. Cycl. Agroecosyst. 2009, 83, 27. [CrossRef]

7. Zhang, H.; Wang, X.; Feng, Z.; Pang, J.; Lu, F.; Ouyang, Z.; Zheng, H.; Liu, W.; Hui, D. Soil temperature and moisture sensitivities of soil $\mathrm{CO}_{2}$ efflux before and after tillage in a wheat field of Loess Plateau, China. J. Environ. Sci. 2011, 23, 79-86. [CrossRef]

8. Zhang, H.; Zhou, X.; Lu, F.; Pang, J.; Feng, Z.; Liu, W.; Ouyang, Z.; Wang, X. Seasonal dynamics of soil CO $\mathrm{CO}_{2}$ efflux in a conventional tilled wheat field of the Loess Plateau, China. Ecol. Res. 2011, 26, 735-743. [CrossRef]

9. Peterson, B.L.; Hanna, L.; Steiner, J.L. Reduced soil disturbance: Positive effects on greenhouse gas efflux and soil N losses in winter wheat systems of the southern plains. Soil Till. Res. 2019, 191, 317-326. [CrossRef]

10. Eshel, G.; Lifschitz, D.; Bonfil, D.J.; Sternberg, M. Carbon exchange in rainfed wheat fields: Effects of long-term tillage and fertilization under arid conditions. Agric. Ecosyst. Enviorn. 2014, 195, 112-119. [CrossRef]

11. Zakharova, A.; Midwood, A.J.; Hunt, J.E.; Graham, S.L.; Artz, R.R.E.; Turnbull, M.H.; Whitehead, D.; Millard, P. Loss of labile carbon following soil disturbance determined by measurement of respired $\delta^{13} \mathrm{CO}_{2}$. Soil Biol. Biochem. 2014, 68, 125-132. [CrossRef]

12. Pandey, D.; Agrawal, M.; Bohra, J.S.; Adhya, T.K.; Battacharyya, P. Recalcitrant and labile carbon pools in a sub-humid tropical soil under different tillage combinations: A case study of rice-wheat system. Soil Till. Res. 2014, 143, 116-122. [CrossRef]

13. La Scala, J.N.; Bolonhezi, D.; Pereira, G.T. Short-term soil $\mathrm{CO}_{2}$ emission after conventional and reduced tillage of a no-till sugar cane area in southern Brazil. Soil Till. Res. 2006, 91, 244-248. [CrossRef]

14. Chavez, L.F.; Amado, T.J.C.; Bayer, C.; La Scala, J.N.; Escobar, L.F.; Fiorin, J.E.; Campos, B.H.C.D. Carbon dioxide efflux in a rhodic hapludox as affected by tillage systems in southern Brazil. Rev. Brasil. Ciên. Solo 2009, 33, 325-334. [CrossRef]

15. Teixeira, L.G.; Fukuda, A.; Panosso, A.R.; Lopes, A.; La Scala, J.N. Soil $\mathrm{CO}_{2}$ emission as related to incorporation of sugarcane crop residues and aggregate breaking after rotary tiller. Eng. Agríc. 2011, 31, 1075-1084. [CrossRef]

16. Wood, T.E.; Detto, M.; Silver, W.L. Sensitivity of Soil Respiration to Variability in Soil Moisture and Temperature in a Humid Tropical Forest. PLoS ONE 2013, 8, e80965. [CrossRef]

17. Sierra, C.A.; Trumbore, S.E.; Davidson, E.A.; Vicca, S.; Janssens, I. Sensitivity of decomposition rates of soil organic matter with respect to simultaneous changes in temperature and moisture. J. Adv. Model. Earth Syst. 2015, 7, 335-356. [CrossRef]

18. Manzoni, S.; Schimel, J.P.; Porporato, A. Responses of soil microbial communities to water stress: Results from a meta-analysis. Ecology 2012, 93, 930-938. [CrossRef]

19. Moyano, F.E.; Manzoni, S.; Chenu, C. Responses of soil heterotrophic respiration to moisture availability: An exploration of processes and models. Soil Biol. Biochem. 2013, 59, 72-85. [CrossRef]

20. Moldrup, P.; Deepagoda, T.K.K.C.; Hamamoto, S.; Komatsu, T.; Kawamoto, K.; Rolston, D.E.; de Jonge, L.W. Structure-dependent water-induced linear reduction model for predicting gas diffusivity and tortuosity in repacked and intact soil. Vadose Zone J. 2013, 12, 1-11. [CrossRef]

21. Bhattacharyya, P.; Nayak, A.K.; Mohanty, S.; Tripathi, R.; Shahid, M.; Kumar, A.; Raja, R.; Panda, B.B.; Roy, K.S.; Neogi, S.; et al. Greenhouse gas emission in relation to labile soil C, N pools and functional microbial diversity as influenced by 39 years long-term fertilizer management in tropical rice. Soil Till. Res. 2013, 129, 93-105. [CrossRef] 
22. Ding, W.; Yu, H.; Cai, Z.; Han, F.; Xu, Z. Responses of soil respiration to $\mathrm{N}$ fertilization in a loamy soil under maize cultivation. Geoderma 2010, 155, 381-389. [CrossRef]

23. Schwendenmann, L.; Veldkamp, E.; Brenes, T.; O'Brien, J.J.; Mackensen, J. Spatial and temporal variation in soil $\mathrm{CO}_{2}$ efflux in an old-growth neotropical rain forest, La Selva, Costa Rica. Biogeochemistry 2003, 64, 111-128. [CrossRef]

24. Silva-Olaya, A.M.; Cerri, C.E.P.; La Scala, N., Jr.; Dias, C.T.S.; Cerri, C.C. Carbon dioxide emissions under different soil tillage systems in mechanically harvested sugarcane. Environ. Res. Lett. 2013, 8, 1-8. [CrossRef]

25. Moitinho, M.R.; Padovan, M.P.; Panosso, A.R.; La Scala, J.N. Efeito do preparo do solo e resíduo da colheita de cana-de-açúcar sobre a emissão de $\mathrm{CO}_{2}$. Rev. Brasil. Ciên. Solo 2013, 37, 1720-1728. [CrossRef]

26. Oliveira, Z.B.; Carlesso, R.; Knies, A.E.; Martins, J.D. Influência de resíduos vegetais na superfície do solo e de diferentes espaçamentos entre linhas do feijoeiro na temperatura do solo. Rev. Irrig. Botucatu 2015, 20, 33-45. [CrossRef]

27. Moitinho, M.R.; Padovan, M.P.; Panosso, A.R.; de Teixeira, D.B.; Ferraudo, A.S.; La Scala, J.N. On the spatial and temporal dependence of $\mathrm{CO}_{2}$ emission on soil properties in sugarcane (Saccharum spp.) production. Soil Till. Res. 2015, 148, 127-132. [CrossRef]

28. Beesley, L. Carbon storage and fluxes in existing and newly created urban soils. J. Environ. Manag. 2012, 104, 158-165. [CrossRef]

29. Kindler, R.; Siemens, J.; Kaiser, K.; Walmsley, D.C.; Bernhofer, C.; Buchmann, N.; Cellier, P.; Eugster, W.; Gleixner, G.; Grũnwald, T.; et al. Dissolved carbon leaching from soil is a crucial component of the net ecosystem carbon balance. Glob. Chang. Biol. 2011, 17, 1167-1185. [CrossRef]

30. Martins, J.A.; Dallacort, R.; Inoue, M.H.; Santi, A.; Kolling, E.M.; Coletti, A.J. Probabilidade de precipitação para a microregião de Tangará da Serra, estado do Mato Grosso. Pesq. Agropec. Trop. 2010, 40, 291-296. [CrossRef]

31. EMBRAPA (Empresa Brasileira de Pesquisa Agropecuária). Sistema brasileiro de classificação de solos. In Centro Nacional de Pesquisa em Solos, 2nd ed.; Embrapa Solos: Rio de Janeiro, Brazil, 2013; p. 353. Available online: https://www.embrapa.br/en/ solos/sibcs (accessed on 18 October 2021).

32. Moreira, J.A.A.; Stone, L.F.; Trindade, M.d.G.; Canovas, A.D. A Cultura do Trigo Irrigado no Sistema Plantio Direto. Available online: http:/ / www.infoteca.cnptia.embrapa.br/infoteca/handle/doc/215235 (accessed on 15 August 2021).

33. Panosso, A.R.; Marques, J.; Milori, D.M.B.P.; Ferraudo, A.S.; Barbieri, D.M.; Pereira, G.T.; La Scala, J.N. Soil CO 2 emission and its relation to soil properties in sugarcane areas under Slash-and-burn and Green harvest. Soil Till. Res. 2011, 111, 190-196. [CrossRef]

34. Blair, G.J.; Lefroy, R.D.B.; Lisle, L. Soil carbon fractions based on their degree of oxidation, and the development of a carbon management index for agricultural systems. Aust. J. Agric. Res. 1995, 46, 1459-1466. [CrossRef]

35. Shang, C.; Tiessen, H. Organic matter lability in a tropical oxisol: Evidence from shifting cultivation, chemical oxidation, particle size, density, and magnetic fractionations. Soil Sci. 1997, 162, 795-807. [CrossRef]

36. Pimentel-Gomes, F.; Garcia, C.H. Estatistica Aplicada a Experimentos Agronomicos e Florestais: Exposicao com Exemplos e Orientacoes Para Uso de Aplicativos; Issue 11 of Biblioteca de Ciências Agrárias Luiz de Queiroz; Editora Fealq: Piracicaba, SP, Brazil, 2002; Volume 11, p. 309. Available online: https:/ / repositorio.usp.br/item/001309130 (accessed on 2 September 2021).

37. Christie, D. Resampling with Excel. Teach. Stat. 2004, 26, 9-14. [CrossRef]

38. Mello, J.M.; Couto, E.G.; Amorin, R.S.S.; Chig, L.A.; Johnson, M.S.; Lobo, F.A. Dinâmica dos atributos físico-químicos e variação sazonal dos estoques de carbono no solo em diferentes fitofisionomias do pantanal norte mato-grossense. Rev. Árvore 2015, 39, 325-336. [CrossRef]

39. Felix, G.A.; Paz, I.C.L.A.; Piovezan, U.; Garcia, R.G.; Lima, K.A.O.; Nääs, I.A.; Salgado, D.D.; Pilecco, M.; Belloni, M. Feeding behavior and crop damage caused by capybaras (Hydrochoerus hydrochaeris) in an agricultural landscape. Braz. J. Biol. 2014, 74, 779-786. [CrossRef]

40. Iamaguti, J.L.; Moitinho, M.R.; Teixeira, D.D.B.; Bicalho, E.D.S.; Panosso, A.R.; La Scala, J.N. Preparo do solo e emissão de CO 2 , temperatura e umidade do solo em área canavieira. Rev. Bras. Eng. Agric. Ambient. 2015, 19, 497-504. [CrossRef]

41. Jabro, J.D.; Sainju, U.; Stevens, W.B.; Evans, R.G. Carbon dioxide flux as affected by tillage and irrigation in soil converted from perennial forages to annual crops. J. Environ. Manag. 2008, 88, 1478-1484. [CrossRef]

42. Ussiri, D.A.N.; Lal, R. Long-term tillage effects on soil carbon storage and carbon dioxide emissions in continuous corn cropping system from an alfisol in Ohio. Soil Till. Res. 2009, 104, 39-47. [CrossRef]

43. Varella, R.F.; Bustamante, M.M.C.; Pinto, A.S.; Kisselle, K.W.; Santos, R.V.; Burke, R.A.; Zepp, R.G.; Viana, L.T. Soil fluxes of CO 2 $\mathrm{CO}, \mathrm{NO}$ and $\mathrm{N}_{2} \mathrm{O}$ from an old pasture and from native savanna in Brazil. Ecol. Appl. 2004, 14, 221-231. [CrossRef]

44. Gorissen, A.; Tietema, A.; Joosten, N.N.; Estiarte, M.; Penñuelas, J.; Sowerby, A.; Emmett, B.A.; Beier, C. Climate change affects carbon allocation to the soil in shrublands. Ecosystem 2004, 7, 650-661. [CrossRef]

45. Dijkstra, F.A.; Cheng, W. Moisture modulates rhizosphere effects on C decomposition in two different soil types. Soil Biol. Biochem. 2007, 39, 2264-2274. [CrossRef]

46. Panosso, A.R.; Rodrigues Ribeiro, C.E.; Zanini, J.R.; Pavani, L.C.; Pereira, G.T.; La Scala, J.N. Variabilidade espacial da emissão de $\mathrm{CO}_{2}$, da temperatura e umidade de um latossolo desprovido de vegetação sob diferentes lâminas de molhamento. Semin. Cienc. Agrar. 2009, 30 (Suppl. S1), 1017-1034. [CrossRef]

47. Reicosky, D.C.; Lindstrom, N.J. Fall tillage method: Effect on short-term carbon dioxide flux from soil. Agron. J. 1993, 85, 1237-1245. [CrossRef]

48. Reicosky, D.C.; Dugas, W.A.; Torbert, H.A. Tillage-induced soil carbon dioxide loss from different cropping systems. Soil Till. Res. 1997, 41, 105-118. [CrossRef] 
49. Rochette, P.; Angers, D.A. Soil surface carbon dioxide fluxes induced by spring, summer, and fall moldboard plowing in a sandy loam. Soil Sci. Soc. Amer. J. 1999, 63, 621-628. [CrossRef]

50. Alvarez, R.; Alvarez, C.R.; Lorenzo, G. Carbon dioxide fluxes following tillage from a mollisol in the Argentine Rolling Pampa. Eur. J. Soil Biol. 2001, 37, 161-166. [CrossRef]

51. La Scala, J.N.; Lopes, A.; Marques, J.J.; Pereira, G.T. Carbon dioxide emissions after application of tillage systems for a dark red latosol in southern Brazil. Soil Till. Res. 2001, 62, 163-166. [CrossRef]

52. De Gryze, S.; Six, J.; Merckx, S. Quantifying water-stable soil aggregate turnover and its implication for soil organic matter dynamics in a model study. Eur. J. Soil Sci. 2006, 57, 693-707. [CrossRef]

53. Grandy, A.S.; Robertson, G.P. Land-use intensity effects on soil organic carbon accumulation rates and mechanisms. Ecosystems 2007, 10, 59-74. [CrossRef]

54. $\quad$ D’Andrea, A.F.; Silva, M.L.N.; Curi, M.; de Freitas, D.A.F.; Roscoe, R.; Guimarães, P.T.G. Variações de curto prazo nas emissões de co2 do solo em diferentes sistemas de manejo do cafeeiro. Quím. Nova 2009, 32, 2314-2317. [CrossRef]

55. Lundquist, E.J.; Jackson, L.E.; Scow, K.M. Wet-dry cycles affect dissolved organic carbon in two California agricultural soils. Soil Biol. Biochem. 1999, 31, 1031-1038. [CrossRef]

56. Helal, H.M.; Sauerbeck, D.R. Influence of plant-roots on C and P metabolism in soil. Plant Soil 1984, 76, 175-182. Available online: https:/ / www.jstor.org/stable/42934498 (accessed on 20 September 2021). [CrossRef]

57. Helal, H.M.; Sauerbeck, D.R. Effect of plant-roots on carbon metabolism of soil microbial biomass. J. Plant. Nutrit. Soil Sci. 1986, 149, 181-188. [CrossRef]

58. Gubiani, P.A.; Van Lier, Q.d.J.; Drescher, M.S.; Mezzomo, H.C.; Veiga, C.M.C. Relação entre densidade do solo e conteúdo de água em repetidos ciclos de contração e expansão em um Latossolo. Rev. Brasil. Ciên. Solo 2015, 39, 100-108. [CrossRef]

59. Bavoso, M.A.; da Silva, A.P.; Figueiredo, G.C.; Tormena, C.A.; Giarola, N.F.B. Resiliência física de dois latossolos vermelhos sob plantio direto. Rev. Brasil. Ciên. Solo 2012, 36, 1892-1904. [CrossRef]

60. Panosso, A.R.; Marques, J.J.; Pereira, G.T.; La Scala, J.N. Spatial and temporal variability of soil $\mathrm{CO}_{2}$ emission in a sugarcane area under green and slash-and-burn managements. Soil Till. Res. 2009, 105, 275-282. [CrossRef]

61. Kolton, M.; Marks, A.; Wilson, R.M.; Chanton, J.P.; Kostka, J.E. Impact of warming on greenhouse gas production and microbial diversity in anoxic peat from a Sphagnum-dominated bog (Grand Rapids, Minnesota, United States). Front. Microbiol. 2019, 26, 1-14. [CrossRef]

62. Menichetti, L.; Reyes Ortigoza, A.L.; García, N.; Giagnoni, L.; Nannipieri, P.; Renella, G. Thermal sensitivity of enzyme activity in tropical soils assessed by the Q10 and equilibrium model. Biol. Fertil. Soils 2015, 51, 299-310. [CrossRef]

63. Sjögersten, S.; Aplin, P.; Gauci, V.; Peacock, M.; Siegenthaler, A.; Turner, B.L. Temperature response of ex-situ greenhouse gas emissions from tropical peatlands: Interactions between forest type and peat moisture conditions. Geoderma 2018, 324, 47-55. [CrossRef]

64. Huang, F.; Xiaoxue, D.; Wenwen, L.; Hongtao, J.; Xiaorong, W.; Xiaoning, Z. The effect of temperature on the decomposition of different parts of maize residues in a solonchak. Catena 2021, 201, 105207. [CrossRef]

65. Zornoza, R.; Acosta, J.A.; Gabarrón, M.; Gómez-Garrido, M.; Sánchez-Navarro, V.; Terreno, A.; Martínez- Martínez, S.; Faz, A.; Pastor, A.P. Greenhouse gas emissions and soil organic matter dynamics in woody crop orchards with different irrigation regimes. Sci. Total Environ. 2018, 644, 1429-1438. [CrossRef] [PubMed]

66. Wang, Y.; Hu, C.; Ming, H.; Oenema, O.; Schaefer, D.A.; Dong, W.; Zhang, Y.; Li, X. Methane, Carbon Dioxide and Nitrous Oxide Fluxes in Soil Profile under a Winter Wheat-Summer Maize Rotation in the North China Plain. PLoS ONE 2014, 9, e98445. [CrossRef] [PubMed]

67. Ahmad, W.; Singh, B.; Dijkstra, F.A.; Dala, R.C. Inorganic and organic carbon dynamics in a limed acid soil are mediated by plants. Soil Biol. Biochem. 2013, 57, 549-555. [CrossRef]

68. Bornhofen, E.; Todeschini, M.H.; Stoco, M.G.; Madureira, A.; Marchioro, V.S.; Storck, L.; Benin, G. Wheat Yield Improvements in Brazil: Roles of Genetics and Environment. Crop. Sci. 2018, 58, 1-12. [CrossRef]

69. Pereira, J.F.; da Cunha, G.R.; Moresco, E.R. Improved drought tolerance in wheat is required to unlock the production potential of the Brazilian Cerrado. Crop. Breed. Appl. Biotechnol. 2019, 19, 217-225. [CrossRef]

70. Scheeren, P.L.; Caierão, E.; Silva, M.S.; Nascimento, A.J.; Caetano, V.R.; Bassoi, M.C.; Brunetta, D.; Albrecht, J.C.; Quadros, W.J.; Sousa, P.G.; et al. Challenges to Wheat Production in Brazil. In Proceedings of the International Symposium on Wheat Yield Potential: Challenges to International Wheat Breeding; Reynolds, M.P., Pietragalla, J., Braun, H.-J., Eds.; CIMMYT: Ciudad Obregón, Mexico, 2008; pp. 167-170. Available online: https:/ / repository.cimmyt.org/handle/10883/1274?locale-attribute=en (accessed on 16 December 2021).

71. GaGama, G.F.V.; de Oliveira, R.M.; Pinheiro, D.T.; da Silva, L.J.; dos Santos Dias, D.C.F. Yield and physiological quality of wheat seeds produced under different irrigation depths and leaf Silicon. Semin. Ciênc. Agrár. Londrina 2021, 42, 2233-2252. [CrossRef]

72. Santos, I.S.; Mantovani, E.C.; Venancio, L.P.; da Cunha, F.F.; Aleman, C.C. Controlled water stress in agricultural crops in Brazilian Cerrado. Biosci. J. Uberlândia 2020, 36, 886-895. [CrossRef]

73. Scheeren, P.L.; Caierão, E.; Silva, M.S.; Junior, A.N.; Caetano, V.R.; Bassoi, M.C.; Brunetta, D.; Albrecht, J.C.; Trindade, M.G.; Mori, C.D.; et al. The Brazil country survey. In International Symposium on Wheat Yield Potential: Challenges to International Wheat Breeding; Reynolds, M.P., Pietragalla, J., Braun, H.-J., Eds.; CIMMYT: Ciudad Obregón, Mexico, 2008; pp. 35-38. Available online: https:/ / repository.cimmyt.org/handle/10883/1274?locale-attribute=en (accessed on 16 December 2021). 